\title{
Rare Presentation of Epstein Barr Virus
}

\author{
Ari $\mathrm{A}^{1}$, Ghosh $\mathrm{T}^{2}$, Bose $\mathrm{S}^{3}$, Shetty $\mathrm{PK}^{4}$, Chaudhary $\mathrm{R}^{5}$
}

\begin{abstract}
Two rare complication of infection with the Epstein-Barr virus is the development of hemophagocytic Lymphohistiocytosis and opsoclonus myoclonus syndrome. Here we are describing two cases which are describing these complications of EpsteinBarr virus infection. As they mimic several other condition but a strong suspicion is needed to diagnose these rare complications early as it will help us to reduce morbidity and mortality of these complications.
\end{abstract}

Key words: Hemophagocytic Lymphohistiocytosis, sepsis, Epstein-Barr virus, opsoclonus myoclonus syndrome

\section{Introduction}

E pstein Barr virus (EBV) has a variety of clinical presentations that range from an asymptomatic carrier state to a fatal overwhelming infection. In the majority of the population, EBV causes acute infectious mononucleosis, a self-limiting illness characterized by fever, lymphadenopathy, tonsillopharyngitis, and hepatosplenomegaly ${ }^{1}$. An infrequent complication of EBV infection is the development of Hemophagocytic Lymphohistiocytosis (HLH) and opsoclonus myoclonus syndrome (OMS).

Here we are reporting two cases with these rare presentations of acute EBV which is serologically confirmed in laboratory

\section{The Case (1)}

A nine year female child was admitted in our hospital with the complaint of fever, jaundice, maculopapular rash, anasarca with decreased urine output. On examination she was conscious but disoriented and had jaundice, edema, tachycardia, feeble pulse and hypotension and mild splenomegaly. A provisional diagnosis of sepsis with acute kidney injury was made and was initially treated with normal saline (NS) bolus to correct the shock along with intravenous antibiotics and other supportive management. Initial investigation (Table 1) shows bicytopenia, altered renal function, hyperbilirubinemia otherwise normal LFT, hypofibriginomia, hypertrigyceridemia and hyperferritinemia. On the basis of this investigation bone marrow aspiration has done which shows erythroid hyperplasia with RBC ingested macrophage without
'Dr. Abhijit Ari', RMO CT, Department of Paediatric Medicine, Burdwan Medical College, ${ }^{2}$ Dr. Taraknath Ghosh'2, Department of Paediatric Medicine, Burdwan Medical College, ${ }^{3}$ Dr. Sayan Bose $^{3}$, Resident, Department of Pediatric Medicine, Burdwan Medical College, ${ }^{4}$ Dr. Prashant Kumar Shetty ${ }^{3}$, Department of Paediatric Medicine, Burdwan Medical College, ${ }^{5}$ Dr. Ruchi Chaudhary ${ }^{4}$, Senior Resident, Department of Paediatric Medicine, SMS Medical College.

Address for correspondence:

Dr. Abhijit Ari

E-mail: abhijitari@gmail.com

\section{How to cite}

Ari A, Ghosh T, Bose S, Shetty PK, Chaudhary R. Rare Presentation of Epstein Barr Virus. J Nepal Paediatr Soc 2015;35(3):290-292.

doi: http://dx.doi.org/10.3126/jnps.v35i3.12159

This work is licensed under a Creative Commons Attribution 3.0 License.

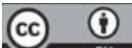

any features of malignancy. On the basis of the clinical features and laboratory investigation initial diagnosis had changed to $\mathrm{HLH}$. To know the cause different viral antibody titer was estimated which shows positivity for EBV. Oral prednisolone has started at the dose of $2 \mathrm{mg} / \mathrm{kg} /$ day from day 4 of admission along with intravenous antibiotics. Her general condition and other clinical features has improved and all abnormal laboratory features became normal. She was discharged 13 days after admission.

\section{The Case (2)}

An eight year old male child presented with high grade fever for one week and active convulsion with altered sensorium 
for two days. On admission patient GCS was 9/15, febrile $\left(101^{\circ} \mathrm{F}\right)$, having tachycardia but otherwise vitals stable. He had maculopapular skin rash present all over the body but predominant on trunk. His bilateral pupils were normal in size and normally reacting to light, neck rigidity and Kerning's sign positive, reflexes are not exaggerated, plantar reflex bilateral extensor but there was no neurological deficit. There is mild splenomegaly without hepatomegaly. Investigations revealed hemoglobin: $9.7 \mathrm{gm} / \mathrm{dl}$; total leukocyte count: $16.0 \times$ $10^{9} /$; differential leukocyte count: polymorphs 67\%, lymphocytes $27 \%$, monocytes $3 \%$, and eosinophils $3 \%$; and platelet count: $150 \times 10^{9} / \mathrm{I}$. Serum sodium was 139 $\mathrm{mmol} / \mathrm{l}$, serum potassium $4.5 \mathrm{mmol} / \mathrm{l}$, blood urea 27 $\mathrm{mg} / \mathrm{dl}$, serum creatinine $0.5 \mathrm{mg} / \mathrm{dl}$, random blood sugar $91 \mathrm{mg} / \mathrm{dl}$, serum bilirubin $1.2 \mathrm{mg} / \mathrm{dl}$, serum alkaline phosphatase $1095 \mathrm{IU} / \mathrm{I}, \mathrm{SGPT} 103 \mathrm{IU} / \mathrm{I}$, serum proteins $6.6 \mathrm{gm} / \mathrm{dl}$, and serum albumin $3 \mathrm{gm} / \mathrm{dl}$. Examination of the cerebrospinal fluid revealed proteins $49.4 \mathrm{mg} / \mathrm{dl}$, and sugar $49.8 \mathrm{mg} / \mathrm{dl}$ (corresponding blood sugar was $127.4 \mathrm{mg} / \mathrm{dl}$ ); total cell count was $15 / \mathrm{mm}^{3}$ (polymorphs $30 \%$ and lymphocytes $70 \%$ ). Gram's stain and AFB stain were negative. Initial laboratory investigations and lumber puncture report shows acute viral encephalitis. Antiviral and antibiotic has started along with the supportive management.

On $5^{\text {th }}$ day of admission he had involuntary, arrhythmic, high- amplitude, conjugate ocular movements in all directions. When asked to look at a target, his visual fixation was disrupted by bursts of high-frequency, conjugate ocular oscillations that had horizontal, vertical, and torsional components, suggestive of opsoclonus. He also had sudden brief involuntary jerky movements of his limbs, trunk, and head, suggestive of myoclonus. The myoclonic movements increased on sitting or standing. Viral serology has sent which shows Epstein Barr virus VCA antigen IgG and IgM positivity. Other viral serology was negative. Chest X-ray, USG abdomen and MRI brain of the child was normal.

Patient was diagnosed as a case of opsoclonus myoclonus syndrome with Epstein Barr virus infection. Oral prednisolone at $2 \mathrm{mg} / \mathrm{kg} /$ day all symptoms along opsoclonus myoclonus were subsided with 10days therapy. Then after steroid was tapered from $10^{\text {th }}$ day onwards. At 1-month follow-up the patient was asymptomatic.

\section{Discussion}

HLH was first described in 1939 and has since been broken down into primary and secondary $\mathrm{HLH}^{2}$. Primary
Table 1: Laboratory Values on Admission

\begin{tabular}{|l|c|}
\hline Lab Tests & Values \\
\hline Total Leucocyte Count & $19700 / \mathrm{mm}^{3}$ \\
\hline Neutrophil & $38 \%$ \\
\hline Lymphocyte & $56 \%$ \\
\hline Monocyte & $1 \%$ \\
\hline Eosinophil & $5 \%$ \\
\hline Haemoglobin & $8.2 \mathrm{~g} \%$ \\
\hline Platelet count & $74000 / \mathrm{mm}^{3}$ \\
\hline Lactate dehydrogenase & $1857 \mathrm{IU} / \mathrm{L}$ \\
\hline Sodium & $154 \mathrm{mEq} / \mathrm{L}$ \\
\hline Potassium & $3.4 \mathrm{mEq} / \mathrm{L}$ \\
\hline Urea & $242 \mathrm{mg} / \mathrm{dL}$ \\
\hline Creatinine & $1.4 \mathrm{mg} / \mathrm{dL}$ \\
\hline Glucose & $74 \mathrm{mg} / \mathrm{dL}$ \\
\hline Protein & $4.9 \mathrm{~g} / \mathrm{dL}$ \\
\hline Albumin & $1.5 \mathrm{~g} / \mathrm{dL}$ \\
\hline Aspartate aminotransferase & $130 \mathrm{IU} / \mathrm{L}$ \\
\hline Alanine aminotransferase & $376 \mathrm{IU} / \mathrm{L}$ \\
\hline Alkaline phosphatise & $1060 \mathrm{IU} / \mathrm{l}$ \\
\hline Bilirubin, total & $7.4 \mathrm{mg} / \mathrm{dL}$ \\
\hline Fibrinogen & $140 \mathrm{mg} / \mathrm{dL}$ \\
\hline Ferritin & $9387 \mathrm{ng} / \mathrm{ml}$ \\
\hline PT & $16 \mathrm{~s}$ \\
\hline aPTT & $25 \mathrm{~s}$ \\
\hline EBV & Negative \\
\hline EBV VCA Antigen & 14.2 \\
\hline EBV IgM Antibody & 57.4 \\
\hline EBV IgG Antibody & \\
\hline & \\
\hline
\end{tabular}

$\mathrm{HLH}$, also termed familial $\mathrm{HLH}$, is an autosomal recessive disease with an identical phenotype to secondary $\mathrm{HLH}$. More than $70 \%$ of patients with familial HLH develop the disease at $<1$ year of age, although familial forms have been reported into early adulthood ${ }^{3}$. Secondary $\mathrm{HLH}$ is associated with immunologic stimulation caused by malignancies and bacterial or congenital infections. The most common causes of secondary $\mathrm{HLH}$ are viral infect ions by EBV, CMV, Parvo virus B19 and HIV. EBV-related secondary HLH may occur at any age. A secondary form of HLH may also occur in patients with normal immune systems. However, it may also be seen in patients with immune system defects ${ }^{2,3}$.

Precise mechanism of EBV-induced $\mathrm{HLH}$ is that EBV-infected B cells stimulate cytotoxic T lymphocytes leading to hypercytokinemia and stimulation of histolytic cells. On the other hand, EBV causes stimulation, generation and uncontrolled secretion of T-and NK-cells, as well as generation of IL2, INFa and IL6. These materials are said $t o$ be responsible for 
Hemophagocytic Lymphohistiocytosis. There is another mechanism by which EBV stimulates membrane protein (LMP-1) in cells. The cells exceedingly secrete INFa, leading to macrophages activation ${ }^{4,5}$.

As the signs and symptoms of EBV-induced $\mathrm{HLH}$ imply, the differential diagnosis is extremely broad, particularly in a critically ill patient. The hematologic and clinical abnormalities often suggest sepsis, leukaemia, lymphoma, or systemic autoimmune vasculitis as the underlying cause.

In our second patient was diagnosed as having OMS caused by EBV and the diagnosis was based on demonstration of antibody titers in the serum.

The term 'opsoclonus' is defined as chaotic, conjugate, multifactor, back-to-back, saccadic eye movements without intersaccadic latency. Although the exact pathophysiology of opsoclonus remains unclear, findings of recent pathological and functional MRI studies suggest that disinhibition of the fastigial nucleus of the cerebellum is involved. The classic concept of damage to the omnipause cells in the pontine raphe is not supported by autopsy studies ${ }^{6}$. Opsoclonus is often precipitated or exacerbated by blinking or eyelid closure, both of which may suppress omnipause neurons. OMS is encountered in patients with encephalitis, in association with certain neoplasms (notably, neuroblastoma in children and gynecological cancers in adults), and certain toxins. The onconeuronal antibodies associated with OMS are anti-Ri antibodies (gynecologic cancers) and, less frequently, anti-Hu, anti-Yo, and anti-Ma-2 antibodies ${ }^{6}$. Epstein-Barr virus, coxsackie virus, and enterovirus have been incriminated in OMS. Epstein-Barr virus, coxsackie virus, and enterovirus have been incriminated in $\mathrm{OMS}^{7,8}$. Our patient was treated with corticosteroids which is also cost-effective, easily available, and free of serious side effects when used for a short duration.

\section{Conclusion}

Though EBV infections in most cases are asymptomatic or very few manifestations but it also presents with this rare presentation which should be kept in mind to prevent mortality. Rarely, lifethreatening complications develop that require immediate recognition and treatment. In the presence of severe hemodynamic collapse with pancytopenia, coagulopathy, and hepatosplenomegaly, EBV-induced $\mathrm{HLH}$ should be suspected and warrant determination of ferritin levels, EBV studies, and a bone marrow aspiration to expedite diagnosis and direct life-saving therapy. EBV is also associated with OMS and it is easily treated with corticosteroids with favourable prognosis.

\section{References}

1. Ohga S, Nomura A, Takada H, Hara T. Immunological aspects of Epstein-Barr virus infection. Crit Rev Oncol Hematol 2002;44:203-15.

2. Imashuku S. Clinical features and treatment strategies of Epstein-Barr virus-associated hemophagocytic lymphohistiocytosis. Crit Rev Oncol Hematol 2002;44:259-72

3. Henter JI, Arico M, Egeler RM, et al. HLH-94: a treatment protocol for hemophagocytic lymphohistiocytosis. HLH Study Group of the Histiocyte Society. Med Pediatr Oncol 1997;28:34247

4. Lay JD, Chuang SE, Rowe M, Su IJ. Epstein-Barr virus latent membrane protein-1 mediates up regulation of tumor necrosis $f$ actor-alpha in EBVinfected T cells: implications f or the pathogenesis of hemophagocytic syndrome. I Biomed Sci 2003;10:146-55.

5. Lay JD, T sao CJ, Chen JY, Kadin ME, Su IJ. Up regulation of tumor necrosis $f$ actor-alpha gene by Epstein-Barr virus and activation of macrophages in Epstein-Barr virus-infected $T$ cells in the pathogenesis of hemophagocytic syndrome. J Clin Invest 1997;100:1969-979.

6. Dalmau J, Rosenfeld MR. Paraneoplastic syndromes of the CNS. Lancet Neurol 2008;7:32740.

7. Sheth RD, Horwitz SJ, Aronoff S, Gingold M, Bodensteiner JB. Opsoclonus myoclonus syndrome secondary to Epstein-Barr virus infection. J Child Neurol 1995;10:297-99.

8. Kuban KC, Ephros MA, Freeman RL, Laffell LB, Bresnan MJ. Syndrome of opsoclonusmyoclonus caused by Coxsackie B3 infection. Ann Neurol 1983;13:69-71. 